\title{
Crimean congo hemorrhagic fever: Introduction and overview of the cases reported from Pakistan
}

Hoor Shumail ${ }^{1}$, Shah Khalid ${ }^{2 *}$, Sher Wali ${ }^{2}$, Maqsood Anwar ${ }^{2}$, Syeda Asma Taskeen ${ }^{2}$ and Syed Inzimam U1 Haq ${ }^{2}$

1. Women University Mardan, KPK-Pakistan

2. Department of Botany, Islamia College Peshawar, KPK-Pakistan

*Corresponding author's email: shahkhalid@icp.edu.pk

Citation

Hoor Shumail, Shah Khalid, Sher Wali, Maqsood Anwar, Syeda Asma Taskeen and Syed Inzimam U1 Haq. Crimean congo hemorrhagic fever: Introduction and overview of the cases reported from Pakistan. Pure and Applied Biology. Vol. 9, Issue 4, pp2456-2460. http://dx.doi.org/10.19045/bspab.2020.90260

Received: 01/04/2020 Revised: 01/07/2020

Accepted: 07/07/2020

Online First: 28/07/2020

\section{Abstract}

Crimean Congo hemorrhagic fever is a tick borne lethal zoonotic disease caused by Crimean Congo hemorrhagic fever virus belonging to the genus Nairovirus and Family Bunyaviridae. It contains Single stranded negative sense segmented RNA genome. The host range of CCFHV includes domestic as well as wild animals and birds. The incubation period of the disease varies from 3 to 13 days depending on the mode of transmission of disease, resulting in high grade fever, headache, dizziness, Photophobia, low blood pressure, muscle pain, vomiting, diarrhea, abdominal pain, hemorrhages, multi organ failure and death. No specific treatment is available so far, suspected cases are given supportive treatment and an antiviral agent Ribavirin. It is a global epidemic and was reported for the first time in Pakistan in 1976. Since 2000 sporadic cases have been reported in Pakistan mostly effecting Baluchistan and KP province due to the cross-border trade and migration of human beings and animals. Proper surveillance systems and guidelines need to be established to control and prevent the spread of disease.

Keywords: Crimean Congo Hemorrhagic Fever; Epidemic; Pakistan

\section{Introduction}

Crimean Congo Hemorrhagic fever (CCHF)

is a lethal zoonotic hemorrhagic fever with a case fatality rate of up to 40 percent during outbreaks. The disease is caused by a tick borne RNA virus that belongs to the genus Nairovirus and family Bunyaviridae [1-5]. It contains single stranded, negative sense segmented RNA genome where the Small (S) segment encodes for viral nucleoproteins, Medium (M) segment encodes for glycoproteins and the largest (L) segment encodes for RNA dependent RNA polymerase enzyme [6-9]. The host range of Crimean Congo Hemorrhagic Fever Virus $(\mathrm{CCHFV})$ includes humans and a wide range of domestic and wild animals and birds such as cattle's, sheep's, goats, hares, hedgehogs and ostriches [10-12]. Immature ticks feed primarily on birds and small mammals, while the adults actively feed on larger mammals, including hares, wild and domesticated cattle's, sheep's, goats or humans [13]. There are several important factors that play a 
significant role in the spread of diseases such as exchange and trade of livestock between countries, transmission of vector through migratory birds, contact with infected ticks, blood and tissues of infected animals, Trans mucosal and conjunctival inoculation of an infectious agent from patient to their family members, doctors and health care workers $[12,14,15]$. The incubation period of the disease varies from 3 to 13 days depending on the route of infection such as 3 days after tick bite, 5-6 days after contact with infected livestock blood or tissue and infected human blood [14, 15]. The disease progresses rapidly, triggering up febrile illness including fever, headache, dizziness, photophobia, myalgia, arthralgia, abdominal pain, vomiting, diarrhea, increased heart rate, lymphadenopathy, rashes with a complication of hemorrhages and multiple organ failure causing death in few days [16, 17]. Cases are confirmed by finding $\mathrm{CCHF}$ virus specific $\mathrm{IgG}$ titer in their serum using ELIZA and RT PCR [18]. There is no specific treatment available, supportive treatment such as hematological support in case of hemorrhages is usually followed. An Antiviral agent such as ribavirin is also administered which has shown positive results in few cases when administered orally. Inactivated mouse brain vaccine is available only in Bulgaria [19]. Moreover, the pathogen causing the disease is a renowned potential bioterrorism agent and need biohazard group IV pathogen safety measures.

\section{Epidemiology}

$\mathrm{CCHF}$ is endemic globally, the disease affected people from different continents Africa, Eastern Europe and Asia. Pakistan is an endemic region for $\mathrm{CCHF}$ just like other countries of Asia such as Afghanistan, India, Iraq, Iran, Oman, Saudi Arabia, Kuwait, Dubai, Russia, China and many more [1, 2, 12]. An increase in the number of cases is observed every year, especially in Pakistan.
The trick is widely distributed, mostly found in less humid regions [20]. In Pakistan, $\mathrm{CCHF}$ is found mostly in provinces with dried plains such as Baluchistan and Khyber Pakhtunkhwa because parts of these regions share Iran and Afghan border. People with their animals migrate, without testing for the disease. Most of the cases reported from our country have an occupational history because the people who deal with livestock such as farm keepers, shepherds, ranchers, butcher, abattoir workers, and health care workers such as physicians, surgeons, and nurses are at high risk. Lack of facilities, awareness, and testing at borders are the main reasons behind the yearly sporadic outbreaks in the country.

\section{Prevalence in Pakistan}

CCHF was reported for the first time in Pakistan in 1976 [4] but a substantial increase has been observed since 2000, with annual reports of 50-60 cases per year. As cases are reported throughout the year but most of the cases are reported from June to October, due to the movement of Cattle's and sheep's which the main hosts of CCHFV vectors are. The first case of CCHFV in Pakistan was reported In Rawalpindi, the patient with CCHFV had abdominal pain and hematemesis when he reported to the hospital. He was considered as a case of abdominal ulcer perforation and underwent laparotomy. The surgeon got infected during the surgery and died after 3 days along with the suspected patient $[2,21,22]$. Few cases were reported from 1977-2000 but detailed information and data is not as such available. From 1976-2005, 14 outbreaks have been reported from various areas of the country [23]. In 2000 CCHFV outbreak in Karachi resulted in deaths of $2 \mathrm{CCHFV}$ patients and the death of 12 patients in Baluchistan. In Dec 2000 one patient was reported as a suspected case of CCHFV which later died. One attendant developed the symptoms but was recovered by treatment with ribavirin. In a report from 2000-2002 a total of 191 cases 
were suspected with 59 death all over the country. In 2002, 2 cases were confirmed of $\mathrm{CCHFV}$ and 1 death reported. From 20032006 a total of 328 cases were suspected with 42 death across the country [24]. In 2005 the first case was reported in Abbottabad which resulted in the death of the patient [4]. The number of cases reported from various parts of the country from 2010 to 2019 is summarized in (Table 1; Fig. 1).

Table 1. Number of cases reported in major areas of Pakistan from 2010 to 2019

\begin{tabular}{|c|c|c|c|c|c|c|c|c|}
\hline \multicolumn{7}{|c|}{ NO. OF CASES REPORTED } & \multirow{3}{*}{ 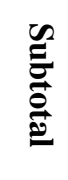 } & \multirow{3}{*}{ 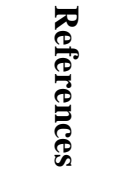 } \\
\hline \multirow[b]{2}{*}{ YEAR } & \multicolumn{6}{|c|}{ MAJOR AREAS OF COUNTRY (CAPITAL, PROVINCES AND AJK) } & & \\
\hline & ISLAMABAD & KPK & PUNJAB & SINDH & BALUCHISTAN & AJK & & \\
\hline 2019 & -- & -- & -- & 20 & 25 & -- & 45 & {$[25,26]$} \\
\hline 2018 & -- & -- & -- & 19 & -- & -- & 19 & [27] \\
\hline 2017 & 01 & -- & 01 & -- & 12 & -- & 14 & [28-31] \\
\hline 2016 & -- & 22 & 16 & 15 & 50 & -- & 103 & [32] \\
\hline 2015* & & & & & & & 161 & [32] \\
\hline 2014 & 04 & 45 & 17 & 05 & 82 & 01 & 154 & [33] \\
\hline 2013 & 04 & 09 & 18 & 02 & 66 & 01 & 100 & [33] \\
\hline 2012 & -- & 09 & 08 & 07 & 38 & -- & 62 & [33] \\
\hline 2011 & 04 & -- & -- & -- & -- & -- & 4 & [34] \\
\hline 2010* & & & & & & & 29 & [24] \\
\hline
\end{tabular}

*For the year 2010 and 2015, provincial data of the reported cases is not available

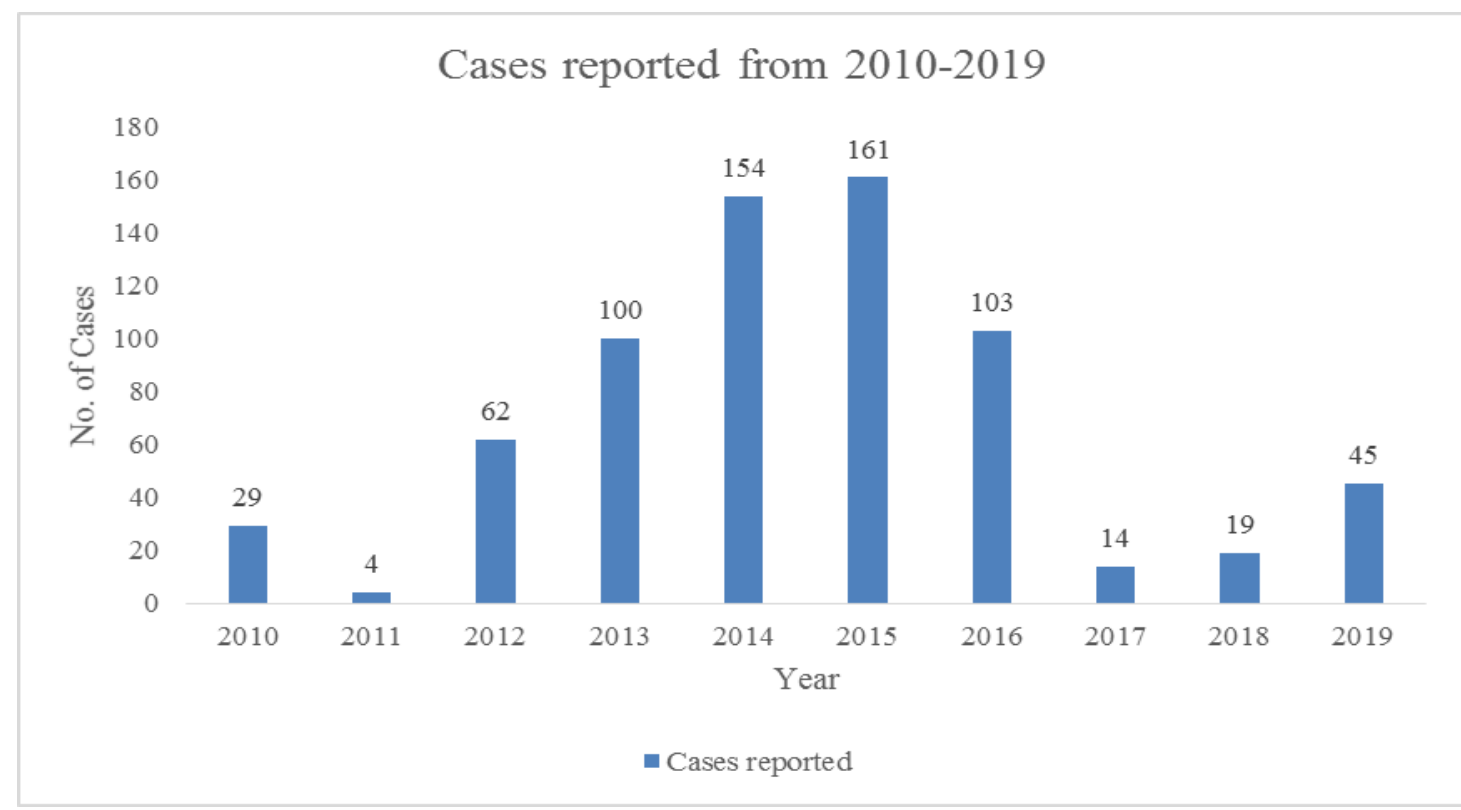

Figure 1. Number of cases reported in major areas of Pakistan from 2010 to 2019

\section{Conclusion}

Pakistan is an endemic area for CCHF, which is a highly contagious disease with a high mortality rate. The main reason behind the spread of CCHF in Pakistan is viral expansion due to the cross border exchange and movement of sacrificial animals with Afghanistan and Iran during the month of Eid ul Azha and through migration of wild animals and birds. CCHF was reported in 
Pakistan for the first time in 1976 but the available data of the reported, suspected and confirmed cases of the disease are very limited due to the absence of proper surveillance systems in Pakistan. Proper guidelines for the control and prevention of the diseases need to be designed and implemented at the national level including campaigns to spread awareness among butchers, shepherds, ranchers, abattoir workers and the general public about the spread and common presentation of the disease, small health camps should be established at the border for testing the persons crossing the border, migratory and domestic birds and sacrificial animals should be sprayed with tick repellents to minimize and control the spread of diseases.

\section{Authors' contributions}

Conceived and designed the idea: H Shumail, $\mathrm{S}$ Khalid \& S Wali, Wrote the paper: $\mathrm{H}$ Shumail, S Khalid, M Anwar, SA Taskeen \& SIU Haq.

\section{References}

1. Ahmad T, Khan M \& Malik S (2016). Re-Emergence of Congo Virus in Pakistan: Call for Preparedness. Biomed Res Ther 3(8): 742-744.

2. Hussain B, Iqbal A \& Abubakar M (2016). Crimean-Congo Hemorrhagic Fever (CCHF): An Emerging Disease in Pakistan. Vet Sci: Res Rev 2(1): 11-22.

3. Aslam S, Latif MS, Daud M, Rahman ZU, Tabassum B, Riaz MS, Khan A, Tariq M \& Husnain T (2016). CrimeanCongo hemorrhagic fever: Risk factors and control measures for the infection abatement. Biomed Rep 4(1): 15-20.

4. Saleem J, Usman M, Nadeem A, Sethi SA \& Salman M (2009). CrimeanCongo hemorrhagic fever: a first case from Abbottabad, Pakistan. Int J Infect Dis 13(3): e121-e123.

5. Papa A, Tsergouli K, Tsioka K, \& Mirazimi A. Crimean-Congo Hemorrhagic Fever: Tick-Host-Virus
Interactions. Front Cell Infect Microbiol 7: 213.

6. Zhou Z, Meng W, Deng F, Xia H, Li T, Sun S, Wang M, Wang H, Zhang Y \& $\mathrm{Hu} Z$ (2013). Complete genome sequences of two crimean-congo hemorrhagic Fever viruses isolated in china. Genome Announc 1(4).

7. Sanchez AJ, Vincent MJ \& Nichol ST. Characterization of the glycoproteins of Crimean-Congo hemorrhagic fever virus. J Virol 76(14): 7263-7275.

8. Vincent MJ, Sanchez AJ, Erickson BR, Basak A, Chretien M, Seidah NG \& Nichol ST (2003). Crimean-Congo hemorrhagic fever virus glycoprotein proteolytic processing by subtilase SKI1. J Virol 77(16): 8640-8649.

9. Carter SD, Surtees R, Walter CT, Ariza A, Bergeron E, Nichol ST, Julian A. Hiscox JA, Thomas A. Edwards TA, John N \& Barr JN (2012). Structure, function, and evolution of the CrimeanCongo hemorrhagic fever virus nucleocapsid protein. J Virol 86(20): 10914-10923.

10. Adam IA, Mahmoud MA \& Aradaib IE (2013). A seroepidemiological survey of Crimean Congo hemorrhagic fever among Cattle in North Kordufan State, Sudan. Virol J 10: 178.

11. Xia H, Zhao J, Li Y, Yin S, Tang S, Zhang Z, Yu J, Kou Z, Fan Z \& Li T (2013). Infection and propagation of Crimean-Congo hemorrhagic fever virus in embryonated chicken eggs. Virus Res 173(2): 344-349.

12. Kamboj A \& Pathak H (2013). CrimeanCongo hemorrhagic fever: a comprehensive review. Vet World 6(10): 812-817.

13. Lindeborg M, Barboutis C, Ehrenborg C, Fransson T, Jaenson TGT, Lindgren PE, Lundkvist A, Nyström F, Salaneck E, Jonas Waldenström J \& Olsen B (2012). Migratory Birds, Ticks, and Crimean- 
Congo Hemorrhagic Fever Virus. Emerg Infect Dis 18(12): 2095-2097.

14. Alam MM, Khurshid A, Sharif S, Shaukat S, Rana MS, Angez M \& Zaidi SSZ (2013). Genetic analysis and epidemiology of Crimean Congo hemorrhagic fever viruses in Baluchistan province of Pakistan. BMC Infect Dis 13: 201.

15. Gozel MG, Dokmetas I, Oztop AY, Engin A, Elaldi N \& Bakir M (2013). Recommended precaution procedures protect healthcare workers from Crimean-Congo hemorrhagic fever virus. Int J Infect Dis 17(11): e1046e1050.

16. Naderi HR, Sheybani F, Bojdi A, Khosravi N \& Mostafavi I (2013). Fatal nosocomial spread of Crimean-Congo hemorrhagic fever with very short incubation period. Am J Trop Med Hyg 88(3): 469-471.

17. Malik S, Diju IU \& Naz F (2011). Crimean Congo Hemorrhagic Fever in Hazara Division. J Ayub Med Coll Abbottabad 23(2): 90-92.

18. Cevik MA, Erbay A, Bodur H, Gulderen E, Bastug A, Kubar A \& Akıncı E (2008). Clinical and laboratory features of Crimean-Congo hemorrhagic fever: predictors of fatality. Int $J$ Infect Dis 12(4): 374-379.

19. Bodur H, Akinci E, Onguru P, Carhan A, Uyar Y, Tanrici A, Cataloluk O \& Kubar A (2010). Detection of Crimean-Congo hemorrhagic fever virus genome in saliva and urine. Int J Infect Dis 14(3): e247-e249.

20. Flick R, Whitehouse CA. CrimeanCongo Hemorrhagic Fever Virus (2005). Curr Mol Med 5(8): 753-760.

21. Mertens M, Schmidt K, Ozkul A \& Groschup MH (2013). The impact of Crimean-Congo hemorrhagic fever virus on public health. Antiviral Res 98(2): 248-260.

22. Saleem M, Shah SZ, Haidari A \& Idrees F (2016). Prevalence of Crimean-Congo hemorrhagic fever in Pakistan and its new research progress. $J$ coast life med 4(4): 259-262.

23. Jamil B, Hasan RS, Sarwari AR, Burton J, Hewson R \& Clegg C (2005). Crimean-Congo hemorrhagic fever: experience at a tertiary care hospital in Karachi, Pakistan. Trans $R$ Soc Trop Med Hyg 99(8): 577-584.

24. Crimean-Congo haemorrhagic fever (CCHF) in Pakistan.

25. Three more Congo virus cases reported in Quetta (2019). The Express Tribune September 1, 2019.

26. Pakistan: Crimean Congo Hemorrhagic Fever deaths in Karachi rises to 20, Rabies death toll rises in Sindh (2019).

27. Another Congo virus case reported in Karachi (2018). Pakistan Today 29 October, 2018.

28. Patient receiving treatment for Congo virus dies at Nishtar Hospital (2017). Pakistan Today Dec 17, 2017.

29. One more death spreads fear of Congo virus in Quetta (2017). Pakitsan Today 6 May, 2017.

30. Another Congo virus patient dies in Quetta (2017). Pakistan Today October 05, 2017.

31. PIMS admits suspected Congo virus patient (2017). Pakistan Today 4 September, 2017.

32. CCHF in Pakistan: cases rise (2016). Weekly Epidemiological Monitor 23 October, 2016.

33. Crimean-Congo haemorrhagic fever in Pakistan (2014). Weekly Epidemiol Monitor 14 December, 2014.

34. Surgeon among four infected with Congo virus (2011). The Nation. 